DOI:10.17951/h.2021.55.3.81-100

\begin{tabular}{lcl}
\hline \multicolumn{1}{c}{ A N N A L E S } \\
UNIVERSITATIS MARIAE CURIE-SKŁODOWSKA \\
LUBLIN - POLONIA \\
VOL. LV, 3 & SECTIOH H \\
\hline
\end{tabular}

\title{
ZENON POKOJSKI
}

zenon.pokojski@umcs.pl

Uniwersytet Marii Curie-Skłodowskiej w Lublinie. Wydział Ekonomiczny

pl. Marii Curie-Skłodowskiej 5, 20-031 Lublin, Polska

ORCID ID: https://orcid.org/0000-0001-5870-6397

\section{Model biznesowy - kontekst innowacji}

Business Model - the Context of Innovation

Keywords: business model; value creation and delivery; innovation; open innovation; open business models

Słowa kluczowe: model biznesowy; kreowanie i dostarczanie wartości; innowacje; otwarte innowacje; otwarte modele biznesowe

JEL: M21; O32; O31; L21

Propozycja cytowania: Pokojski, Z. (2021). Model biznesowy - kontekst innowacji. Annales Universitatis Mariae Curie-Skłodowska, sectio H-Oeconomia, Vol. 55, No. 3.

\begin{abstract}
Theoretical background: The concept of the business model was introduced in the late 1950s, but did not gain any special scientific popularity in the first period. Only the appearance of the Internet and e-business at the turn of the century contributed to the renaissance of this concept. Currently, the concept of the business model is popular among scientists and business practitioners. A great deal of interest is accompanied by an equally large variety of definitions of the concept, but there is no commonly accepted consent as to its components. There is even talk of carelessness in using this concept. Business models need to be constantly developed not only when they become outdated, but also when they appear to be well developed. The proposition of the unique value for the customer, creating, delivering and taking over the value for the stakeholders is associated with innovations that do not have objective economic value in themselves, only their commercialization based on a business model gives such value. Therefore, companies should reorganize their business models to be more open to innovation, in other words, to make them open business models.
\end{abstract}


Purpose of the article: To make a synthetic review of the definitions of a business model available in the economic literature, the role of innovation in this model and to indicate new trends in the interpretation of these concepts.

Research methods: The publication is the result of a research procedure based on a review of the literature on the subject. The evolution of the understanding of the concept of a business model and its components as well as the role of innovation in the model were studied on the basis of an analysis of 69 definitions or conceptualization of the concept.

Main findings: In the second decade of $20^{\text {th }}$ century, new elements appear more and more in the definitions of business models supplemented by innovation processes. Unfortunately, the terminology has not kept pace with the development of the ways of doing business: 1) the concept of the value chain is already too narrow for the complex network structures of various organizations. Value is created and delivered more and more often in complex structures, called partnerships, networks or ecosystems; 2) the current definitions of a business model refer to the phenomenon of value creation both on the supply and demand side, where value is also generated on the part of customers and other stakeholders within, for example, business ecosystems; 3 ) the business model is becoming an increasingly important concept in the field of innovation management, strategy implementation, sustainable development taking into account social and environmental values, and social entrepreneurship; 4) it is believed that the model should be open to open innovation and should favor their commercialization; 5) inviting undefined user/customer communities to cooperate is becoming more and more important. This kind of cooperation requires building open platforms on the Internet (crowdsourcing, co-production or coopetition, open sourcing); 6) it is now believed that the ability to define and redefine an organization's business model is one of the key competences for building the value of an organization.

\begin{abstract}
Abstrakt
Uzasadnienie teoretyczne: Pojęcie modelu biznesowego zostało wprowadzone pod koniec lat 50. XX wieku, ale w pierwszym okresie nie zyskało dużej popularności naukowej. Dopiero pojawienie się internetu i e-biznesu na przełomie wieków przyczyniło się do renesansu tego pojęcia. Obecnie koncepcja modelu biznesowego cieszy się zainteresowaniem zarówno ludzi nauki, jak i praktyków biznesu. Dużemu zainteresowaniu towarzyszy równie duża różnorodność definicji pojęcia, ale brakuje powszechnie akceptowanej zgody co do jej elementów składowych. Mówi się nawet o niedbałości w używaniu tego pojęcia. Modele biznesowe muszą być stale rozwijane nie tylko wtedy, gdy się dezaktualizują, ale również gdy wydają się dobrze rozwinięte. Propozycja unikalnej wartości dla klienta oraz tworzenie, dostarczanie i przejmowanie wartości dla interesariuszy wiąże się z innowacjami, które same w sobie nie mają obiektywnej wartości ekonomicznej, dopiero ich komercjalizacja w oparciu o model biznesowy taką wartość nadaje. Firmy powinny zatem przeorganizować swoje modele biznesowe w taki sposób, by były bardziej otwarte na innowacje, słowem - by to były otwarte modele biznesowe.

Cel artykułu: Dokonanie syntetycznego przeglądu dostępnych w literaturze ekonomicznej definicji modelu biznesowego, wskazanie roli innowacji w tym modelu oraz nowych trendów w interpretacji tych pojęć.

Metody badawcze: Publikacja jest rezultatem postępowania badawczego opartego na przeglądzie literatury przedmiotu. Dokonano badania ewolucji rozumienia pojęcia modelu biznesowego i jego komponentów oraz roli innowacji w modelu na podstawie analizy 69 definicji bądź konceptualizacji pojęcia.

Glówne wnioski: W drugiej dekadzie XX wieku coraz częściej pojawiają się nowe elementy w definicjach modeli biznesowych uzupełnianych procesami innowacji. Niestety, terminologia nie nadąża za rozwojem sposobów prowadzenia biznesu: 1) pojęcie łańcucha wartości jest już zbyt wąskie dla rozbudowanych struktur sieciowych różnych organizacji. Wartość kreowana i dostarczana znajduje się coraz częściej w rozbudowanych strukturach, zwanych partnerstwami, sieciami lub ekosystemami; 2) obecne definicje modelu biznesowego odnoszą się do zjawiska tworzenia wartości zarówno po stronie podaży, jak i po stronie popytu, gdzie wartość powstaje również po stronie klientów i innych interesariuszy w ramach np. ekosystemów biznesu; 3) model biznesowy staje się coraz ważniejszym pojęciem w obszarze zarządzania
\end{abstract}


innowacjami, wdrażania strategii, zrównoważonego rozwoju uwzględniającego wartości społeczne i środowiskowe czy przedsiębiorczości społecznej; 4) uważa się, że model powinien być otwarty na otwarte innowacje i powinien sprzyjać ich komercjalizowaniu; 5) coraz większego znaczenia nabiera zapraszanie do współpracy niezdefiniowanych społeczności użytkowników/klientów. Współpraca tego rodzaju wymaga zbudowania otwartych platform w internecie (crowdsourcing, koprodukcja czy koopetycja, open sourcing); 6) obecnie uważa się, że umiejętność definiowania i redefiniowania modelu biznesowego organizacji należy do kluczowych kompetencji służących budowaniu wartości organizacji.

\section{Wprowadzenie}

Model biznesowy jest jednym z tych magicznych pojęć ekonomicznych, które często są używane i równie często są niedoprecyzowane. Trudno tutaj o zgodę co do wspólnych elementów definicji tego pojęcia (Chesbrough \& Rosenbloom, 2002). Przyjmuje się, że dobry model biznesowy powinien dostarczać odpowiedzi na podstawowe pytania, stawiane już przez Druckera: Kim są nasi klienci i co dla nich stanowi wartość? Jak zarabiać pieniądze? (Edersheim, 2010) Nie wyznaczono jednak wyraźnych granic funkcjonowania tego pojęcia. Magretta (2013) wręcz twierdzi, że „model biznesowy” $i$ „strategia” należą dziś do najbardziej niedbale używanych pojęć z dziedziny zarządzania. Jak wskazuje Porter, „definicja modelu biznesowego jest w najlepszym razie niejasna. Wydaje się odnosić do luźnej koncepcji tego, jak firma prowadzi działalność i generuje przychody, (...) służąc jako wezwanie do błędnego myślenia i złudzeń" (Porter, 2001, s. 74). Doprecyzowuje jednak, że jego zdaniem model biznesowy jest opisem działalności przedsiębiorstwa, które zapewnia mu zyski, sprowadza się więc do określenia roli organizacji w łańcuchu wartości, w jakim działa (Porter, 2006). Pomimo tak żarliwej krytyki części ludzi nauki koncepcja modelu biznesowego jako dziedzina wiedzy z obszaru nauk o zarządzaniu zyskuje w ostatnim okresie na popularności.

\section{Model biznesowy - istota pojęcia}

Pojęcie modelu biznesowego zostało wprowadzone pod koniec lat 50. XX wie$\mathrm{ku}$, ale w pierwszym okresie nie zyskało akceptacji naukowej. Dopiero pojawienie się internetu i e-biznesu na przełomie wieków przyczyniło się do renesansu modelu biznesowego używanego do określenia elementów tego modelu (np. aukcji), jego typów (np. model relacji z klientem, bezpośredni) czy opisu konkretnego przypadku (np. model Della) (Osterwalder, Pigneur \& Tucci, 2005; Zott, Amit \& Massa, 2011). Ta koncepcyjna niejednoznaczność znajduje odzwierciedlenie w różnych definicjach pojęcia, jakie można znaleźć w literaturze przedmiotu. Obecnie koncepcja modelu biznesowego cieszy się zainteresowaniem zarówno ludzi nauki, jak i praktyków biznesu. Ci pierwsi są zgodni co do tego, że każda firma - bez względu na to, czy sobie to uświadamia czy nie - posiada model biznesowy (Chesbrough, 2007, s. 12-17; Teece, 2010, s. 172-194). W swoich publikacjach często podejmują się 
sformułowania własnej definicji omawianego pojęcia, która najlepiej odpowiada potrzebom prezentowanej pracy. Brak konsensusu można częściowo przypisać zainteresowaniu tą koncepcją szerokiego wachlarza dyscyplin: e-biznes, strategia, nowe technologie, systemy informacyjne i informatyczne (Shafer, Smith \& Linder, 2005, s. 199-207). W konsekwencji brakuje powszechnie akceptowanej definicji pojęcia „model biznesowy” (Jørgensen \& Ulhøi, 2010, s. 25-32). Wspomniane niejasności co do definicji i konceptualizacji modelu biznesowego utrudniają przeprowadzenie analizy porównawczej dotychczasowego dorobku naukowego (Foss \& Saebi, 2018, s. 9-21; Zott i in., 2011).

Część ludzi nauki zwraca uwagę na określenie wzajemnego oddziaływania między firmami w tworzeniu wartości i źródeł przychodów, inni zwracają uwagę na innowacyjny sposób generowania przychodów, a jeszcze inni definiują katalog niezbędnych elementów, które składają się na pojęcie modelu biznesowego. Ta sytuacja w konsekwencji prowadzi do formułowania postulatów o konieczności stworzenia wspólnej platformy naukowej w celu poprawienia jakości i efektywności badań modeli biznesowych (Zott, Amit \& Massa, 2010, s. 3). Zott z zespołem zaproponował bardzo ogólne ujęcie tego pojęcia jako: wyrażenie, opis, reprezentacja, architektura, narzędzie koncepcyjne, szablon struktury, metoda, budowa, schemat, zestaw (Zott i in., 2011). Wśród ludzi nauki pierwszej dekady XXI wieku dotychczas dominował pogląd, że model biznesowy odnosi się do dominującej logiki funkcjonowania organizacji, a także sposobu, w jaki ona działa i tworzy wartość dla interesariuszy (Casadesus-Masanell \& Ricart, 2010, s. 195-215).

Próbę usystematyzowania dorobku naukowego w tej dziedzinie podjęli Onetti, Zuchcella, Jones i McDougall-Covin (2012, s. 337-368), którzy dokonali przeglądu literatury zawierającej 70 definicji pojęcia „,model biznesowy” z okresu 1996-2009. Autorzy wyselekcjonowali z tej grupy 48 definicji cytowanych przez różnych autorów w kontekście różnych konfiguracji komponentów modeli biznesu oraz zdefiniowali 26 elementów składowych tych modeli. Następnie wybrali 11 komponentów, które uznali za właściwe dla logiki zrozumienia pojęcia „model biznesowy”. Najczęściej cytowanymi elementami składowymi, występującymi w ponad $50 \%$ analizowanej literatury, okazały się: procesy, działania, łańcuch wartości, klient i relacje z nim, sieci wartości (partnerzy, aktorzy, dostawcy, sojusznicy). W konsekwencji zaproponowano pięć głównych obszarów wymagających poprawy w zakresie definiowania modelu biznesowego:

1. Istnieje potrzeba wyraźnego oddzielenia pojęcia modeli biznesowych od koncepcji i strategii.

2. Powinno się oddzielić pojęcie modeli biznesowych od rezultatów finansowych. Dane finansowe pomagają mierzyć wyniki modelu biznesowego, ale nie są same w sobie jego składowymi.

3. Definicje modeli biznesowych powinny obejmować lokalizacje podejmowanych decyzji, co może mieć znaczenie dla budowy konkurencyjności firmy. 
4. Definicje modeli biznesowych powinny uwzględniać i syntetyzować wcześniejsze prace w tym obszarze, które identyfikują takie elementy składowe jak: działania, łańcuch wartości i sieci wartości.

5. Konceptualizacja modeli biznesowych powinna być w miarę prosta i możliwa do uogólnienia, tak by mogła być zastosowana do firm każdego rodzaju i wielkości.

Saebi i Foss (2015) na potrzeby badań nad dopasowaniem heterogenicznych otwartych strategii innowacji do formuły modelu biznesowego dokonali w 2015 roku autorskiego przeglądu definicji pojęcia modelu biznesowego. W swych pracach skoncentrowali się na tym, co zbliża do zrozumienia omawianego pojęcia. W konsekwencji doszli do wniosku, że modele biznesowe oznaczają podstawową logikę firmy do tworzenia i przejmowania wartości, określając podstawową propozycję wartości, segmenty rynku, do których firma się odwołuje, strukturę łańcucha wartości, która jest potrzebna do realizacji propozycji wartości, oraz mechanizmy wychwytywania wartości, które firma wdraża, w tym jej strategie konkurencji. Podsumowując swoją definicję, wskazali, że najbliżej im do rozumienia tego pojęcia przyjętego przez Teece'a (2010, s. 191), zgodnie z którym „,istotą modelu biznesowego jest określenie sposobu, w jaki przedsiębiorstwo dostarcza wartość klientom, zachęca ich do płacenia za tę wartość i przekształcenia tych płatności w zyski”.

Definicja Saebi i Foss łączy bezpośrednio organizacyjne aspekty transakcji i wzajemnych relacji z tworzeniem i przejmowaniem wartości. Model biznesowy powinien zatem określać:

- treść transakcji (zbiór podstawowych działan, które firma prowadzi, np. propozycja wartości),

- strukturę transakcji (jednostki organizacyjne wykonujące te czynności i sposoby łączenia tych jednostek),

- zarządzanie transakcjami (np. mechanizmy kontroli jednostek organizacyjnych i powiązania między tymi jednostkami) (Zott \& Amit, 2010).

W oparciu o różne możliwe konfiguracje elementów składowych firmy mogą zaprojektować różne modele biznesowe, które odzwierciedlają ich strategiczne wybory.

Kolejni autorzy - Massa, Tucci i Afuah (2017, s. 73-104) - dokonali krytycznej analizy badań nad modelem biznesowym. Analizie poddano 216 artykułów, z których 89 zawierało 71 oryginalnych definicji opublikowanych w wiodących pismach naukowych z zakresu zarządzania w okresie 1995-2016. Termin „model biznesowy” pojawił się w tekście, streszczeniu lub słowach kluczowych. Autorzy pogrupowali literaturę na trzy obszary według interpretacji funkcji modelu biznesowego:

- modele biznesowe jako atrybuty prawdziwych firm posiadających realny wpływ na działalność biznesową,

- modele biznesowe jako schemat poznawczy bądź językowy,

- modele biznesowe jako formalna koncepcja prezentująca opis działania organizacji. 
Przeprowadzona analiza pozwoliła też na wskazanie trzech różnych zjawisk, będących prawdopodobnie konsekwencją różnych interpretacji roli modelu biznesowego:

- sposób, w jaki firmy prowadzą działalność,

- sposób, w jaki interesariusze organizacji interpretują prowadzoną działalność,

- sposób, w jaki można przedstawić konceptualizację modelu za pomocą symboli czy wzorów matematycznych lub graficznych.

Podane interpretacje roli i funkcji modeli biznesowych wskazały na znaczenie tego konstruktu pojęciowego w badaniach. Zdaniem autorów ten brak rozróżnienia ma duże znaczenie i jest źródłem wielu nieporozumień. W niewielu publikacjach wyraźnie wspomina się o tym problemie, przez co brakuje wyznaczenia jasnych granic badań. Jednym ze sposobów rozwiązania tego problemu jest po prostu wyjaśnienie w każdym badaniu, jaki pogląd na model jest zakładany. Czy przyjęto rozumienie modelu biznesowego jako atrybutu organizacji, jako schematu poznawczego czy też jako formalnej prezentacji pojęcia. Zestawienie wybranych definicji modelu biznesowego zaprezentowano w tabeli 1 .

Tabela 1. Wybrane definicje/konceptualizacje modeli biznesowych i najważniejsze komponenty

\begin{tabular}{|c|c|c|}
\hline Autorzy (rok)* & Definicje, konceptualizacje & Komponenty \\
\hline $\begin{array}{l}\text { Linder \& Cantrell, } \\
(2000)\end{array}$ & $\begin{array}{l}\text { Model biznesowy ,jest podstawową logiką tworzenia } \\
\text { wartości organizacji” (s. 1) }\end{array}$ & - tworzenie wartości \\
\hline Amit \& Zott (2001) & $\begin{array}{l}\text { „Model biznesowy przedstawia zawartość, strukturę } \\
\text { i zarządzanie transakcjami zaprojektowane tak, aby } \\
\text { tworzyć wartość poprzez wykorzystywanie okazji } \\
\text { biznesowych” (s. 493-494) }\end{array}$ & $\begin{array}{l}\text { - treść transakcji } \\
\text { - struktura transakcji } \\
\text { - zarządzanie transakcjami } \\
\text { - tworzenie wartości }\end{array}$ \\
\hline $\begin{array}{l}\text { Chesbrough } \\
\text { \& Rosenbloom } \\
(2002)\end{array}$ & $\begin{array}{l}\text { „Model biznesowy zapewnia spójną strukturę, która } \\
\text { wymaga charakterystyki technologii i potencjałów } \\
\text { jako danych wejściowych, następnie przekształca je } \\
\text { poprzez klientów i rynki w wyniki ekonomiczne. Model } \\
\text { biznesowy jest zatem pomyślany jako narzędzie sku- } \\
\text { piające się na rozwoju technologii i tworzeniu wartości } \\
\text { ekonomicznej” (s. 532) }\end{array}$ & $\begin{array}{l}\text { - propozycja wartości } \\
\text { - segment rynku } \\
\text {-struktura łańcucha wartości } \\
\text { - struktura kosztów i poten- } \\
\text { cjał zysku } \\
\text { - pozycja firmy w sieci } \\
\text { wartości } \\
\text { - konkurencyjna strategia }\end{array}$ \\
\hline Afuah (2004) & $\begin{array}{l}\text { „Model biznesowy to sposób zarabiania pieniędzy. Jest } \\
\text { zbiorem czynności, które firma wykonuje, aby zaofe- } \\
\text { rować swoim klientom korzyści, których oczekują, za } \\
\text { które są skłonni zapłacić, a firma mogła zarobić” (s. 2) }\end{array}$ & $\begin{array}{l}\text { - działania (co, jak, kiedy) } \\
\text { - korzyści dla klienta } \\
\text { - zysk }\end{array}$ \\
\hline $\begin{array}{l}\text { Shafer, Smith \& } \\
\text { Linder (2005) }\end{array}$ & $\begin{array}{l}\text { „Biznes jest przede wszystkim zainteresowany tworze- } \\
\text { niem wartości i przejmowaniem zysków z tej wartości, } \\
\text { a model jest po prostu prezentacją rzeczywistości. } \\
\text { Model biznesowy definiujemy jako opis podstawowej } \\
\text { strategii firmy i strategicznej możliwości wyboru i prze- } \\
\text { chwytywania wartości w ramach sieci wartości” (s. 202) }\end{array}$ & $\begin{array}{l}\text { - strategiczne wybory } \\
\text { - tworzenie wartości } \\
\text { - przechwytywanie wartości } \\
\text { - sieć wartości }\end{array}$ \\
\hline
\end{tabular}


Pobrane z czasopisma Annales $\mathrm{H}$ - Oeconomia http://oeconomia.annales.umcs.pl

Data: 26/04/2023 15:49:14

MODEL BIZNESOWY - KONTEKST INNOWACJI

\begin{tabular}{|c|c|c|}
\hline Autorzy (rok)* & Definicje, konceptualizacje & Komponenty \\
\hline Chesbrough (2007) & $\begin{array}{l}\text { „Funkcje modelu biznesowego to: } \\
\text { - sformułowanie propozycji wartości, tj. wartość two- } \\
\text { rzoną dla użytkowników, } \\
\text { - zidentyfikowanie segmentu rynku, tj. użytkowników, } \\
\text { do których skierowana jest oferta, } \\
\text { - zdefiniowanie struktury łańcucha wartości, w którym } \\
\text { firma tworzy i dystrybuuje swoją ofertę oraz określa } \\
\text { komplementarność aktywów do umacniania swojej } \\
\text { pozycji w tym łańcuchu, } \\
\text { - określenie mechanizmu generowania przychodów } \\
\text { i oszacowanie struktury kosztów oraz potencjału stwo- } \\
\text { rzenia oferty, biorąc pod uwagę propozycję wartości } \\
\text { i strukturę łańcucha wartości, } \\
\text { - opisanie pozycji firmy w sieci wartości, łączącej } \\
\text { dostawców i klientów, } \\
\text { - sformułowanie konkurencyjnej strategii, za pomocą } \\
\text { której innowacyjna firma zdobędzie i utrzyma przewagę } \\
\text { nad rywalami” (załącznik 1, s. 13) }\end{array}$ & $\begin{array}{l}\text { - propozycja wartości } \\
\text { - segment rynku } \\
\text { - struktura łańcucha wartości } \\
\text { - aktywa uzupełniające } \\
\text { - mechanizm generowania } \\
\text { dochodów } \\
\text { - struktura kosztów i poten- } \\
\text { cjał zysku } \\
\text { - pozycja firmy w sieci war- } \\
\text { tości, ekosystem (dostawcy, } \\
\text { klienci, konkurenci) } \\
\text { - strategia konkurencji }\end{array}$ \\
\hline $\begin{array}{l}\text { Johnson, Christen- } \\
\text { sen \& Kagerman } \\
(2008)\end{array}$ & $\begin{array}{l}\text { „Model biznesowy składa się z czterech powiązanych } \\
\text { ze sobą elementów w celu tworzenia i dostarczania war- } \\
\text { tości”. Są to: propozycja wartości dla klienta, formuła } \\
\text { zysku, kluczowe zasoby i kluczowe procesy (s. 57-68) }\end{array}$ & $\begin{array}{l}\text { - propozycja wartości dla } \\
\text { klienta } \\
\text { - formuła zysku } \\
\text { - kluczowe zasoby } \\
\text { - kluczowe procesy }\end{array}$ \\
\hline Zott \& Amit (2010) & $\begin{array}{l}\text { „Model biznesowy definiujemy jako opisujący } \\
\text { zawartość, strukturę oraz zarządzanie transakcjami } \\
\text { zaprojektowanymi w celu tworzenia wartości poprzez } \\
\text { wykorzystywanie okazji biznesowych” (s. 219) }\end{array}$ & $\begin{array}{l}\text { - struktura transakcji } \\
\text { - treść transakcji } \\
\text { - zarządzanie transakcjami }\end{array}$ \\
\hline $\begin{array}{l}\text { Casadesus-Masanell } \\
\text { \& Ricart (2010) }\end{array}$ & $\begin{array}{l}\text { „Model biznesowy odnosi się do logiki firmy, sposobu } \\
\text { jej działania i tworzenia wartości dla swoich interesariu- } \\
\text { szy” (s. 196) } \\
\text { „Model biznesowy firmy jest odzwierciedleniem reali- } \\
\text { zowanej strategii” (s. 205) }\end{array}$ & $\begin{array}{l}\text { - logika firmy } \\
\text { - konkretne wybory, jak } \\
\text { organizacja musi działać } \\
\text { - konsekwencje tych wy- } \\
\text { borów } \\
\text { - tworzenie wartości dla } \\
\text { klientów }\end{array}$ \\
\hline $\begin{array}{l}\text { Itami \& Nishino } \\
(2010)\end{array}$ & $\begin{array}{l}\text { „Model biznesowy składa się z dwóch elementów: } \\
\text { systemu biznesowego i modelu zysku” (s. 364) }\end{array}$ & $\begin{array}{l}\text { - system biznesowy } \\
\text { - model zysku }\end{array}$ \\
\hline $\begin{array}{l}\text { Osterwalder \& } \\
\text { Pigneur (2010) }\end{array}$ & $\begin{array}{l}\text { Opisuje model biznesowy będący uzasadnieniem tego, } \\
\text { jak organizacja tworzy, dostarcza i wychwytuje wartość } \\
\text { (s. 14) }\end{array}$ & $\begin{array}{l}\text { - segmenty klientów } \\
\text { - propozycja wartości } \\
\text { - kanały } \\
\text { - relacje z klientami } \\
\text { - strumienie przychodów } \\
\text { - kluczowe zasoby } \\
\text { - kluczowe działania } \\
\text { - kluczowi partnerzy } \\
\text { - struktura kosztów }\end{array}$ \\
\hline $\begin{array}{l}\text { Bocken, Short, } \\
\text { Rana \& Evens } \\
(2014)\end{array}$ & $\begin{array}{l}\text { „(...) model biznesowy może zapewnić uporządkowa- } \\
\text { ny sposób zrównoważonego myślenia biznesowego } \\
\text { poprzez mapowanie celu i możliwości do tworzenia } \\
\text { wartości w sieci i przechwytywania tej wartości w fir- } \\
\text { mach” (s. 67) } \\
\text { To wymaga „szerszego [niż w przypadku tradycyjnych } \\
\text { modeli biznesowych] spectrum zainteresowanych stron, } \\
\text { które należy wziąć pod uwagę w tworzeniu wartości, } \\
\text { jak np. środowisko i społeczeństwo” (s. 78) }\end{array}$ & $\begin{array}{l}\text { - cel, powód } \\
\text { - możliwości/zasoby (do } \\
\text { tworzenia wartości) } \\
\text { - sieć } \\
\text { - interesariusze } \\
\text { - środowisko } \\
\text { - społeczeństwo } \\
\text { - przechwytywanie wartości }\end{array}$ \\
\hline
\end{tabular}


Pobrane z czasopisma Annales H - Oeconomia http://oeconomia.annales.umcs.pl Data: 26/04/2023 15:49:14

\begin{tabular}{|c|c|c|}
\hline Autorzy (rok)* & Definicje, konceptualizacje & Komponenty \\
\hline $\begin{array}{l}\text { Upward \& Jones } \\
\text { (2016) }\end{array}$ & $\begin{array}{l}\text { „Opis tego, jak firma definiuje i osiąga sukces w czasie” } \\
\text { (s. 98) }\end{array}$ & $\begin{array}{l}\text { - definicja sukcesu } \\
\text { - jak osiągać sukces w czasie }\end{array}$ \\
\hline Wells (2016) & $\begin{array}{l}\text { „Mówiąc ogólnie, model biznesowy można zdefiniować } \\
\text { jako posiadający trzy elementy składowe: } \\
\text { - sieć wartości i ofertę produktów/usług, która definiu- } \\
\text { je, w jaki sposób firma jest powiązana wewnętrznie oraz } \\
\text { z innymi firmami (tj. jak tworzona jest wartość), } \\
\text { - propozycja wartości, która określa, w jaki sposób } \\
\text { produkty i/lub usługi są prezentowane konsumentom } \\
\text { w zamian za pieniądze (tj. sposób przechwytywania } \\
\text { wartości), } \\
\text { - kontekst norm prawnych, zachęt, cen, polityki rządu } \\
\text { itp. (tj. jak wartość mieści się w szerszych ramach } \\
\text { społeczno-ekonomicznych)”(s. 37) }\end{array}$ & $\begin{array}{l}\text { - sieć wartości i produkt/ } \\
\text { usługa } \\
\text { - propozycja wartości } \\
\text { - ramy społeczno-ekono- } \\
\text { miczne }\end{array}$ \\
\hline
\end{tabular}

* Tabela zawiera definicje i konceptualizacje modeli biznesowych uporządkowane chronologicznie w porządku rosnącym. Definicje to stwierdzenia wyjaśniające, czym jest model biznesowy. Konceptualizacje to stwierdzenia, które pośrednio definiują model biznesowy, wyjaśniając, jak on działa.

Źródło: opracowanie własne na podstawie (Massa, Tucci \& Afuah, 2017, załącznik s. 9-23; Saebi \& Foss, 2015, s. 201-213), uzupełnienia własne.

Przegląd definicji pojęcia „model biznesowy” i jego komponentów wskazuje na dużą rozbieżność rozumienia tego terminu. Niektórzy naukowcy jasno określają, jak interpretują to pojęcie. Redagowane są np. definicje, według których model biznesowy jest zwięzłą prezentacją tego, jak są ze sobą powiązane zestawy zmiennych decyzyjnych firmy (Morris, Schindehutte \& Allen, 2005, s. 726-735), lub też jest narzędziem koncepcyjnym, które pozwala wyrazić logikę biznesową firmy (Osterwalder i in., 2005). Wielu ludzi nauki wskazuje na inny aspekt, dowodząc, że modele biznesowe mogą być źródłem przełomowych innowacji (Johnson, Christensen \& Kagermann, 2008, s. 57-68), mogą wpływać na wyniki firmy (Amit \& Zott, 2008, s. 1-26; Zott \& Amit, 2015) czy na komercjalizację ich technologii (Chesbrough \& Rosenbloom, 2002).

Niezależnie od różnic w definicjach można wskazać obszary wspólne, sprowadzające się do trzech kluczowych funkcji modeli biznesowych, a mianowicie propozycji wartości, tworzenia i dostarczania wartości oraz przechwytywania wartości. Różnie jednak odnoszą się one do czynności, które należy wykonywać, kto ma je wykonywać, a także do sposobu i czasu, w jakim mają być wykonywane, aby te cele osiągać. Koźmiński podkreśla, że podstawą sukcesu każdej firmy jest stosowany przez nią pomysł na tworzenie wartości i wychwytywanie wartości, czyli uzyskiwanie najwyższych marż w łańcuchu firm, które uczestniczą w wytworzeniu produktu i dostarczeniu go odbiorcy (Koźmiński, 2004, s. 119). Te kluczowe funkcje stanowią istotę modelu biznesowego (Bocken, Short, Rana \& Evens, 2014, s. 43; Vanhaverbeke \& Chesbrough, 2014). 


\section{Model biznesowy a innowacje}

Modele biznesowe muszą być stale rozwijane - nie tylko wtedy, gdy się dezaktualizują, ale również wtedy, gdy wydają się dobrze rozwinięte czy dojrzałe. Zarządzanie modelami biznesowymi w warunkach tak dużej turbulencji zmian otoczenia rynkowego i społecznego jest działalnością ryzykowną i niepewną. Tworzenie unikalnej wartości i przewagi konkurencyjnej wiąże się z innowacjami, które powinny być wpisane w ,kod genetyczny” modelu biznesowego. Chesbrough konstatuje, że bardziej cenna może być mierna technologia realizowana w ramach świetnego modelu biznesowego niż wielka technologia wykorzystywana przez przeciętny model biznesowy (Chesbrough, 2010, s. 354). Poszukuje się też rozwiązań elastycznych i zwinnych, które wspierają szybkie rekonfiguracje modelu (Jabłoński, 2016, s. 49-64).

Firmy mogą dysponować bogatym programem inwestycyjnym, dużym potencjałem badawczo-rozwojowym, zdolnością generowania nowych wynalazków czy technologii, ale małą zdolnością wdrażania innowacji w swoich modelach biznesowych. W rezultacie nawet świetne technologie mają małe szanse na komercjalizację. Rzeczą istotną jest więc rozwijanie przez organizacje zdolności do wprowadzania innowacji swoich modeli biznesowych.

Innowacja sama w sobie nie posiada obiektywnej wartości. Wartość ekonomiczna nie jest znana do czasu, kiedy zostanie skomercjalizowana i zaakceptowana przez rynek w oparciu o model biznesowy. Ta sama technologia skomercjalizowana na dwa różne sposoby prawdopodobnie przyniesie różne stopy zwrotu. Niektóre innowacje można skomercjalizować w ramach istniejącego modelu biznesowego firmy, natomiast dla sukcesu innych potrzebne jest powołanie nowego podmiotu, zbudowanego w oparciu o nowy model biznesowy, jeszcze inne zaś mogą generować dochód np. przez ich licencjonowanie. Oczywiście są też autorzy czy właściciele, którzy chronią swoje pomysły w oparciu o patent i poszukują sposobu ich komercjalizacji, ale ten sposób zarządzania kapitałem intelektualnym ma jedynie wartość utajoną, która może nigdy nie zamienić się w wartość ekonomiczną.

Chesbrough w swojej pierwszej książce na temat otwartych innowacji z 2003 roku traktował model biznesowy w sposób statyczny. Nabyte doświadczenia, szczególnie w trakcie badań firmy Xerox w jej centrum badawczym PARC, pozwoliły zwrócić uwagę na wagę powiązań innowacji i modelu biznesowego (Chesbrough \& Rosenbloom, 2002, s. 529). Autor ten przeanalizował 35 projektów badawczych, które „opuściły mury” firmy, a które próbowano komercjalizować w bardzo różny sposób. Większości z nich nie udało się odnieść sukcesu (poza Xeroxem), natomiast te które uzyskały akceptację rynkową, wygenerowały w sumie wartość rynkową większą od firmy, z której wyszły. Podsumowując badanie, autor konkluduje, że firmy muszą rozwijać zdolność do innowacji swoich modeli biznesowych tak dobrze, jak dobre są ich pomysły, know-how i nowe technologie (Chesbrough, 2010, s. 356).

Podobne badania przeprowadził Christensen, przeanalizował bowiem 26 innowacji dotyczących modeli biznesowych, z których 10 zakończyło się porażką, a 16 
- sukcesem. Aby zrozumieć związki przyczynowo-skutkowe zaobserwowanych zależności, Bever, Bartman i Christensen (2020) dokonali oceny przypadków w oparciu o 20 aspektów oraz przeprowadzili 60 wywiadów z członkami zarządów. Autorzy zauważyli, że starając się wprowadzać zmiany, menedżerowie próbują stworzyć nowe przedsięwzięcie w ramach istniejącej jednostki biznesowej, która funkcjonuje w obrębie starych współzależności i sztywnych ram istniejącego modelu biznesowego. Zwrócili uwagę, że taki proces zmian powinien rozpocząć się od sprawdzenia, w jakim stopniu wprowadzana innowacja jest spójna z istniejącym modelem biznesowym. Wskazali, że modele biznesowe firm o dobrej pozycji rynkowej przechodzą ewolucję, która zaczyna się od stworzenia jednostki biznesowej i jej modelu działania, potem wchodzi w fazę utrzymania i rozwijania jednostki biznesowej, a kończy się „wyciśnięciem” maksimum efektywności. Zdaniem tych badaczy, aby odnosić sukcesy we wdrażaniu innowacji, należy skupić się na tworzeniu nowych modeli biznesowych, a nie na zmienianiu tych już istniejących. Paradoks, z którym muszą się mierzyć menedżerowie, polega na tym, że zdolności i umiejętności przydatne dla istniejącego modelu są z reguły nieprzydatne, a czasem nawet szkodliwe dla nowego modelu biznesowego.

Dyer, Gregersen i Christensen (2012, s. 137-152), badając wpływ innowacji na wartość rynkową firm, sprawdzili, jaki odsetek tej wartości można przypisać istniejącym produktom, usługom i rynkom ${ }^{1}$. Jeśli wartość rynkowa firmy była wyższa niż przepływy pieniężne generowane przez obecne dziedziny działalności, firma wykazywała tzw. premię innowacyjną. Autorzy dowodzą, że w procesach innowacyjnych mamy do czynienia z podziałem na umiejętności odkrywcze i umiejętności wykonawcze. Liderzy wysoce innowacyjnych firm uzyskiwali ponadprzeciętne wyniki w zakresie tych pierwszych i znacznie niższe tych drugich. $Z$ kolei w badaniu menedżerów wyższego szczebla bez szczególnych osiągnięć w dziedzinie innowacyjności zdecydowanie lepsze wyniki mieli w dziedzinie zdolności wykonawczych. Budowanie innowacyjnych i otwartych modeli biznesowych organizacji polega na umiejętności łączenia i uzupełniania się tych umiejętności.

Istnieje wiele sposobów komercjalizacji pomysłów, idei czy technologii, z których prawdopodobnie niewiele - jak twierdzi Chesbrough (2006) - odniesie sukces. Wskazuje on na konieczność ewolucji modelu biznesowego w sześciostopniowej skali dojrzałości poziomu rozwoju.

W tabeli 2 przedstawiono różne rodzaje modeli biznesowych firm w kontekście powiązań z procesami innowacyjnymi i zarządzaniem własnością intelektualną dla budowania wartości przedsiębiorstwa i rozwijania jego przewagi konkurencyjnej.

1 Autorzy w 2010 roku przeprowadzili analizę 25 najbardziej innowacyjnych firm w latach 2005-2009 z listy Business Week opartej na wynikach ankiety przeprowadzonej przez Boston Consulting Group. 
Pobrane z czasopisma Annales H - Oeconomia http://oeconomia.annales.umcs.pl

Data: 26/04/2023 15:49:14

MODEL BIZNESOWY - KONTEKST INNOWACJI

Tabela 2. Struktury modelu biznesowego w powiązaniu z procesami innowacji i zarządzania własnością intelektualną

\begin{tabular}{|c|c|c|c|}
\hline Typ & Model biznesowy & Procesy innowacyjne & Zarządzanie własnością intelektualną \\
\hline 1 & niezróżnicowany & brak & brak \\
\hline 2 & zróżnicowany & doraźne (ad hoc) & reaktywne \\
\hline 3 & segmentowy & zaplanowane & obronne \\
\hline 4 & otwarty na otoczenie & wspierane zewnętrznie & udostępnianie aktywów \\
\hline 5 & zintegrowany & połączone z modelem biznesowym & element składowy aktywów \\
\hline 6 & adaptacyjny & $\begin{array}{l}\text { identyfikują i adaptują nowe modele } \\
\text { biznesowe }\end{array}$ & strategiczny składnik aktywów \\
\hline
\end{tabular}

Źródło: opracowanie własne na podstawie (Chesbrough, 2006, s. 111).

Firma typu 1 nie definiuje swojego modelu biznesowego i nim nie zarządza (szerzej: Pokojski, 2017). Konkuruje na rynku ceną, dostępnością towaru lub usługi. Rzadko wdraża innowacje, raczej kopiuje je od innych. Jest również bezbronna przed kopiowaniem przez innych, dlatego nie jest w stanie kontrolować swojej przyszłości. Przykładem tego typu firm są rodzinne restauracje, niezależne księgarnie czy sklepy, kawiarnie, fryzjerzy i wiele rodzajów usług rozpoczynających swoją działalność.

Firma typu 2 tworzy pewien stopień zróżnicowania w swoich produktach i usługach. Pojawiają się tutaj innowacje, ale mają one charakter innowacji ad hoc. Firma koncentruje się na swojej podstawowej działalności, zaniedbując przy tym wspieranie innowacji. Zarządzanie własnością intelektualną jest raczej reaktywne, przypadkowe, służy bardziej jej ochronie niż pozyskaniu. Sytuacja ta jest dość typowa dla indywidualnych wynalazców czy młodych firm typu spin-off, które pragną swój pomysł skomercjalizować, lecz nie są w stanie go rozwijać.

Firma typu 3 rozwija własną działalność badawczo-rozwojową, komercjalizując obiecujące projekty. Ponieważ swoją działalność opiera na dużych przychodach i niskich kosztach, jest wrażliwa na cenę swoich produktów. Firma tego typu myśli o innowacjach z perspektywy produktu lub stosowanej technologii, zaniedbuje przy tym jednak informacje płynące $\mathrm{z}$ rynku.

Firma typu 4 zmienia swoją orientację z innowacji rozwoju produktu, procesu czy technologii w kierunku innowacji rozwoju relacji z rynkiem. Jednakże nadal koncentruje swoje działania badawczo-rozwojowe na obecnie obsługiwanym segmencie rynku, dlatego nie jest odporna na niebezpieczeństwo pojawienia się innowacji z obszarów pozornie niepowiązanych. Zarządzanie własnością intelektualną staje się funkcją biznesową. Wartość intelektualna jest postrzegana jako rodzaj aktywów niematerialnych firmy, służących budowaniu jej wartości.

W firmie typu 5 partnerzy handlowi i klienci mają sformalizowany dostęp do jej procesów innowacyjnych. Co istotne, firma wymaga respektowania zasady wzajemności. Stara się też zrozumieć partnerów biznesowych i klientów w celu zidentyfikowania rozbieżności między ich modelami biznesowymi a jej własnym. Innowacje stają się elementem wewnętrznego DNA firmy. Zarządzanie własnością intelektualną 
ma bardziej strategiczny charakter. Firma aktywnie poszukuje innowacji na rynku w celu wzmocnienia swojej oferty. Ponadto zaczyna zarządzać własnością intelektualną jako składnikiem swoich aktywów.

Firma typu 6 angażuje się w prowadzenie eksperymentów w celu zbadania alternatywnych sposobów osiągania zysku na innowacjach. Niektóre z nich dla zbadania nowych modeli biznesowych tworzą spółki specjalnego przeznaczenia (Special Purpose Vehicle, SPV) w celu zarządzania ryzykiem prowadzenia niektórych projektów (jest to sposób komercjalizacji innowacji poza obecnym modelem) oraz traktują je jako inwestycje podwyższonego ryzyka. Modele biznesowe partnerów są integrowane z modelem firmy, która z kolei integruje swój model biznesowy z modelem kluczowych klientów. Własność intelektualna jest traktowana jako strategiczny składnik aktywów, umożliwiający firmie wejście na nowe rynki, a także pozwala budować ekosystemy wokół siebie.

Warto zauważyć pojawiające się publikacje dotyczące innowacji w modelu biznesowym dla zrównoważonego rozwoju (Bocken i in., 2014; Evans, Bergendahl, Gregory, Ryan \& Tan, 2009; Geissdoerfer, Vladimirova \& Evans, 2018, s. 401-416; Schaltegger, Lüdeke-Freund \& Hansen, 2012, s. 95-119; Tykkyläinen \& Ritala, 2021, s. 684-697). Bocken z zespołem (2014, s. 44) innowacje w modelu biznesowym na rzecz zrównoważonego rozwoju definiuje jako innowacje, które tworzą znaczący, pozytywny i/lub znacznie zmniejszony negatywny wpływ na środowisko i/lub społeczeństwo poprzez zmiany w sposobie, w jaki organizacja i jej sieć tworzy wartość, dostarcza i przechwytuje wartość lub zmienia propozycje tej wartości.

\section{Model biznesowy a otwarte innowacje}

Otwarte innowacje i otwarte modele biznesowe zyskały popularność w ostatnich latach dzięki pracom Chesbrougha $(2003,2006)$. W otwartych innowacjach od samego początku badano związek między procesami badawczo-rozwojowymi firmy a modelem biznesowym (Vanhaverbeke \& Chesbrough, 2014, s. 51). Chesbrough wskazuje na ścisłe powiązanie działalności innowacyjnej organizacji lub jej partnerów innowacyjnych z modelem biznesowym, który uzupełnia słowem „otwarty”. Tego rodzaju modele biznesowe powinny prowadzić z jednej strony do poprawy wyników finansowych (m.in. poprzez obniżenie kosztów innowacji), z drugiej zaś generować dodatkowe przychody poprzez sprzedaż niewykorzystywanej wiedzy firmy (szerzej: Pokojski, 2018).

Otwarty na innowacje model biznesowy firmy to model, który kieruje poszukiwaniem działań innowacyjnych z zewnętrznych lub wewnętrznych źródeł. Firmy muszą szukać innowacji rozwijających ich model biznesowy z dowolnych źródeł, z których mogą osiągnąć korzyści we właściwym czasie. Powinny być dużo bardziej otwarte na współdzielenie innowacji lub ich licencjonowanie, jeżeli nie pasują do ich modelu. Kiedy pomysły i innowacje są integralnymi elementami modelu bizneso- 
wego firmy i tworzą dodatkową dźwignię rozwoju innych obszarów biznesu, można wówczas powiedzieć, że firmy te stosują otwarty model biznesowy (Chesbrough, 2006; Saebi \& Foss, 2015, s. 210; Vanhaverbeke \& Chesbrough, 2014). Natomiast gdy brakuje innowacji, brakuje również innych wymaganych elementów pozwalających na przekształcenie idei w wartość rynkową.

Chesbrough (2006, s. 2-3), wyjaśniając istotę otwartych modeli biznesowych, zwraca uwagę na nowy trend polegający na ,specjalizacji w procesie innowacyjnym": jedni opracowują nowatorski pomysł, a drudzy przenoszą ideę na rynek. Ten podział poprawił skuteczność procesu innowacyjnego oraz wydajność badań i rozwoju. Otwarty model biznesowy dzięki podziałowi specjalizacji ma zdolność do komercjalizacji większej liczby pomysłów (w tym pomysłów zewnętrznych), tym samym ma zdolność budowania i przejmowania większej wartości, wykorzystując kluczowe aktywa, zasoby lub procesy nie tylko własnej firmy, lecz także innych firm.

Otwarte modele biznesowe mogą zatem z jednej strony prowadzić do poprawy wyników finansowych poprzez obniżenie kosztów innowacji, z drugiej zaś generować dodatkowe przychody poprzez sprzedaż technologii w oparciu o umowy licencyjne i działania typu spin-off w sytuacji, gdy nie mogą być skomercjalizowane z zyskiem przez firmę. Otwarte modele biznesowe są wobec tego ściśle powiązane z działaniami innowacyjnymi firmy lub jej zewnętrznymi partnerami innowacyjnymi. $Z$ tego powodu modele te nazywane są także „otwartym modelem biznesowym innowacji” lub „nowym modelem biznesowym innowacji”.

Jak już wspomniano, istota modelu biznesowego sprowadza się do tworzenia i dostarczania wartości oraz do przechwytywania tej wartości. Firmy mogą tworzyć wartość poprzez oferowanie nowych produktów lub usług wycenianych przez docelową grupe klientów. Mogą również przechwytywać wartość, tworząc unikalne zasoby lub aktywa, w których firma ma przewagę konkurencyjną. Pomyślne zakończenie projektu badawczo-rozwojowego nie gwarantuje sukcesu. Dopiero dostarczenie produktu klientowi finalnemu i jego akceptacja mogą być źródłem satysfakcji finansowej przedsiębiorstwa. Jednak wprowadzenie nowej oferty na rynek może być procesem złożonym, w którym niezbędna jest bliska współpraca $\mathrm{z}$ innymi firmami w kanałach dystrybucji wzdłuż łańcucha wartości lub w ramach sieci wartości. W takich przypadkach wartość jest tworzona wspólnie z innymi partnerami, z którymi trzeba się nią podzielić.

Niektóre firmy odchodzą od własnych innowacji produktowych, rozwijając swoją sieć innowacji i partnerów w łańcuchu/sieci wartości, by tą drogą budować przewagę konkurencyjną (Nambisan \& Sawhney, 2009, s. 128-135). Firma inicjująca współpracę może zorganizować wspólne badania i zachęcić partnerów do połączenia sił w celu przyspieszenia procesów innowacji, a tym samym zwiększenia przewagi.

Skuteczność pozyskiwania innowacji z wewnętrznych i zewnętrznych źródeł wymaga dostosowania tego procesu do modelu biznesowego firmy (Zott i in., 2011). Saebi i Foss (2015, s. 201-213) dowodzą, że do strategii otwartych innowacji należy dopasować model biznesowy w odniesieniu do zawartości, struktury i zarządzania. Podstawowe strategie innowacji dla otwartych modeli biznesowych opisuje tabela 3. 
Pobrane z czasopisma Annales H - Oeconomia http://oeconomia.annales.umcs.pl

Data: 26/04/2023 15:49:14

ZENON POKOJSKI

Tabela 3. Podstawowe strategie innowacji dla otwartych modeli biznesowych

\begin{tabular}{|c|c|c|c|c|}
\hline \multirow{3}{*}{ 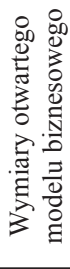 } & \multicolumn{4}{|c|}{ Strategie otwartych innowacji } \\
\hline & $\begin{array}{l}\text { strategia innowacji } \\
\text { oparta na rynku }\end{array}$ & $\begin{array}{l}\text { strategia innowacji } \\
\text { oparta na „tłumie” }\end{array}$ & $\begin{array}{l}\text { strategia wspólnoty } \\
\text { innowacyjnej }\end{array}$ & $\begin{array}{l}\text { strategia innowacji } \\
\text { oparta na sieci }\end{array}$ \\
\hline & $\begin{array}{l}\text { - otwarty model bizne- } \\
\text { sowy skoncentrowany } \\
\text { na skuteczności }\end{array}$ & $\begin{array}{l}\text { - otwarty model bizne- } \\
\text { sowy skoncentrowany } \\
\text { na głównych użytkow- } \\
\text { nikach }\end{array}$ & $\begin{array}{l}\text { - model biznesowy } \\
\text { otwarty na współpracę }\end{array}$ & $\begin{array}{l}\text { - otwarty model } \\
\text { biznesowy oparty na } \\
\text { platformie współpracy }\end{array}$ \\
\hline 雚 & $\begin{array}{l}\text { - propozycja wartości } \\
\text { koncentrująca się na } \\
\text { efektywności, oparta na } \\
\text { redukcji kosztów trans- } \\
\text { akcyjnych i kosztów } \\
\text { koordynacji }\end{array}$ & $\begin{array}{l}\text { - propozycja wartości } \\
\text { ukierunkowana na } \\
\text { użytkownika, wkład ze } \\
\text { społeczności użytkow- } \\
\text { ników }\end{array}$ & $\begin{array}{l}\text { - radykalne innowacje } \\
\text { i otwarcie się na nowe } \\
\text { segmenty rynku }\end{array}$ & $\begin{array}{l}\text { - model biznesowy } \\
\text { działa jako platforma } \\
\text { otwartej innowacji dla } \\
\text { wielu zainteresowanych } \\
\text { stron }\end{array}$ \\
\hline 莺 & $\begin{array}{l}\text { - redefinicja roli } \\
\text { wewnętrznego systemu } \\
\text { B+R } \\
\text { - struktura skoncentro- } \\
\text { wana na efektywności }\end{array}$ & $\begin{array}{l}\text { - faza ideowa innowacji } \\
\text { „zlecona thumowi” }\end{array}$ & $\begin{array}{l}\text { - użytkownicy, dostaw- } \\
\text { cy, klienci i konkurenci } \\
\text { stają się kluczowymi } \\
\text { partnerami w innowacji }\end{array}$ & $\begin{array}{l}\text { - reorganizacja systemu } \\
\text { produkcji i dystrybucji } \\
\text { - potrzeba uzupełnienia } \\
\text { sieci wewnętrznej }\end{array}$ \\
\hline 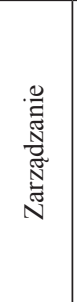 & $\begin{array}{l}\text { - wynagrodzenie dla } \\
\text { dostawców wiedzy } \\
\text { zewnętrznej } \\
\text { - stosowanie „,integra- } \\
\text { cji” ekspertów” w celu } \\
\text { wchłonięcia dostępnej } \\
\text { na rynku wiedzy i umie- } \\
\text { jętności }\end{array}$ & $\begin{array}{l}\text { - nagrody finansowe lub } \\
\text { pozafinansowe dla ze- } \\
\text { wnętrznych dostawców } \\
\text { wiedzy } \\
\text { - zachęty dla własnych } \\
\text { pracowników w celu } \\
\text { większego angażowa- } \\
\text { nia się i zarządzania } \\
\text { wspólnotami }\end{array}$ & $\begin{array}{l}\text { - umowa określająca } \\
\text { podział nagrody między } \\
\text { organizacją a zewnętrz- } \\
\text { nym dostawcą wiedzy } \\
\text { - zachęty dla własnych } \\
\text { pracowników do współ- } \\
\text { pracy z głównymi użyt- } \\
\text { kownikami i partnerami } \\
\text { zewnętrznymi }\end{array}$ & $\begin{array}{l}\text { - motywowanie } \\
\text { własnych pracowników } \\
\text { do angażowania się we } \\
\text { współpracę z licznymi } \\
\text { partnerami wiedzy (oso- } \\
\text { by fizyczne, przedsię- } \\
\text { biorstwa, społeczności) } \\
\text { - redystrybucja zagro- } \\
\text { żeń i korzyści }\end{array}$ \\
\hline
\end{tabular}

Źródło: opracowanie własne na podstawie (Saebi \& Foss, 2015, s. 201-213).

Chesbrough twierdzi, że otwarte modele biznesowe muszą pozwalać na pewien stopień organizacyjnej ,,przepuszczalności” ułatwiający przepływ informacji i rozpowszechnianie wiedzy ponad granicami firmy. Firma może przyjąć model otwarcia dośrodkowy (do wewnątrz), w którym dominuje proces przepływu wiedzy z otoczenia do przedsiębiorstwa, albo model odśrodkowy (na zewnątrz), gdzie dominuje proces przepływu wiedzy z przedsiębiorstwa do otoczenia, albo proces mieszany, gdzie mają miejsce przepływy wiedzy zarówno do wewnątrz, jak i na zewnątrz. Saebi i Foss (2015), podzielając tę opinię, podkreślają znaczenie mechanizmów zarządzania i praktyk organizacyjnych wspierających integrację wiedzy zewnętrznej. Zwracają w tym kontekście uwagę na trzy elementy:

- różne strategie innowacji wymagają różnych modeli biznesowych,

- zakres rekonfiguracji modelu biznesowego różni się w zależności od rodzaju strategii modelu otwartych innowacji,

- strategie innowacji charakteryzujące się dużą różnorodnością źródeł wiedzy wymagają modeli biznesowych, które zorientowane są na obsługę dużej ilości informacji. Natomiast w przypadku strategii, które wymagają głębokiej integracji zewnętrznych źródeł wiedzy z działalnością innowacyjną firmy, 
konieczne jest zaprojektowanie modelu biznesowego umożliwiającego ścisłą współpracę i ułatwiającego wzajemną wymianę wiedzy między partnerami.

W otwartych modelach biznesowych coraz większego znaczenia nabiera zapraszanie do współpracy niezdefiniowanych społeczności użytkowników/klientów. Przepływ wiedzy między firmą a jej otoczeniem zewnętrznym jest dwukierunkowy. Współpraca ze społecznościami ma często charakter nieformalny i wiąże się z dużymi kłopotami w zakresie zarządzania takimi projektami. Współpraca tego rodzaju wymaga zbudowania otwartych platform w internecie:

- crowdsourcingu (wykorzystanie tłumu jako źródła wiedzy, jego mądrości) (Chanal \& Caron-Fasan, 2010, s. 318-340; Sopińska, 2013, s. 287-302),

- koprodukcji czy koopetycji (powszechny udział, współpraca ludzi lub firm w poszukiwaniu innowacji, w tym nawet firm konkurujących ze sobą) (Gulati, Nohria \& Zahher, 2000, s. 203-215),

- oprogramowania otwartego źródła (open source software) (Dolińska, 2017, s. 73-83; Lakhani \& Hippel, 2004, s. 303-339).

Curley i Salmelin (2013) wskazują na nowe wyzwania, przed jakimi stają innowacje w otwartych modelach biznesu, gdzie społeczeństwo obywatelskie współpracuje $\mathrm{z}$ biznesem, środowiskiem akademickim i sektorem publicznym, aby inicjować i rozwijać zmiany daleko wykraczające poza zakres tego, co każda organizacja może zrobić samodzielnie (zob. Dzisah \& Etzkowitz, 2008, s. 101-115)². Wyzwaniem jest nowy model innowacji, który autorzy określają mianem „Open Innovation 2.0”. Ich zdaniem nowy model to nowy paradygmat, oparty na zasadach zintegrowanej współpracy, współtworzonej wspólnej wartości, ekosystemach innowacji, dynamicznie rozpowszechnianych technologiach i ich szybkiej implementacji.

Komitet Regionów Unii Europejskiej w opinii pt. „Zlikwidować przepaść innowacyjną" deklaruje, że ,popiera nowe inwestycje w otwarte innowacje i crowdsourcing” (Komitet Regionów, 2013). Jednocześnie podkreśla, że innowacyjne procesy powinny być mocno oparte na popycie oraz zorientowane na użytkowników i konsumentów, którzy stanowią kluczowe podmioty innowacji. Stąd też - zdaniem autorów tej opinii - należy wspierać nowe podejście innowacyjne oparte na dialogu, współpracy i kreatywności, a innowacyjne strategie powinny skupiać się na katalizowaniu otwartych innowacji. Komisja Europejska dostrzegła w tej koncepcji szansę na zdynami-

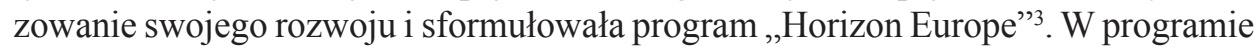

2 Ciekawą koncepcją podkreślającą współpracę organizacji różnych środowisk jest model rozwoju potrójnej helisy (Triple Helix Theory). Etzkowitz zdefiniował działalność innowacyjną jako produkt współpracy pomiędzy trzema typami instytucji: jednostkami sektora nauki, organami administracji rządowej i przedsiębiorstwami sektora prywatnego. Teoria ta wskazuje, że formalne i nieformalne porozumienia zawierane pomiędzy sektorem prywatnym i sektorem publicznym determinują kształt i poziom wzrostu gospodarczego na danym obszarze. Szczególną rolę odgrywają powiązania między organami administracji lokalnej i regionalnej, biznesem oraz sektorem nauki.

3 Program „Horizon Europe” został zaprezentowany przez A. Mangan z Komisji Europejskiej na konferencji pn. „Efektywna współpraca biznesu z nauką w kontekście Konstytucji dla Nauki oraz Konstytucji dla Biznesu", zorganizowanej przez Polskie Forum Akademicko-Gospodarcze w dniu 26 lutego 
jeden $\mathrm{z}$ trzech filarów rozwoju innowacyjności w Unii Europejskiej oparty został na otwartych systemach innowacji. Instytucjonalnym wsparciem tego programu są Europejska Rada Innowacji oraz Europejski Instytut Innowacji i Technologii.

\section{Podsumowanie}

W drugiej dekadzie XXI wieku coraz częściej pojawiają się nowe elementy w definicjach modeli biznesowych uzupełnianych procesami innowacji. Niestety, terminologia nie nadąża za rozwojem sposobów prowadzenia biznesu.

Pojęcie łańcucha wartości jest zbyt wąskie dla rozbudowanych struktur sieciowych różnych organizacji funkcjonujących w rzeczywistości gospodarczej. Co więcej, linearne podejście do budowania wartości już nie wystarcza. Wartość kreowana i dostarczana znajduje się coraz częściej w rozbudowanych strukturach, zwanych partnerstwami, sieciami czy ekosystemami. Pojawia się pojęcie sieci wartości (Bocken i in., 2015; Wells, 2016, s. 36-52). Obecnie to nie duże korporacje konkurują ze sobą, lecz całe ekosystemy (Hearn \& Pace, 2006, s. 55-65).

Wartość tworzą nie tylko firmy jako takie, ale również ich klienci. Tradycyjne teorie zakładały tworzenie wartości, koncentrując się na stronie podaży i ograniczając przewagę konkurencyjną do jednego źródła. To znaczy, że wartość może być tworzona przez producentów czy dostawców usług, a nie przez klientów, natomiast przewaga konkurencyjna generowana jest w oparciu o zasoby i własne działania (Peteraf, 1993, s. 179-191; Porter, 1996, s. 85-90). Obecne definicje modelu biznesowego odnoszą się do zjawiska tworzenia wartości zarówno po stronie podaży, jak i po stronie popytu, gdzie wartość powstaje również po stronie klientów i innych interesariuszy, w ramach np. ekosystemów biznesu. Przewaga konkurencyjna z kolei może opierać się na zasobach i działaniach po stronie podaży i popytu (Massa i in., 2017, s. 75).

Model biznesowy staje się coraz ważniejszym pojęciem w obszarze zarządzania innowacjami (Bever i in., 2020; Chesbrough, 2010; Massa \& Tucci, 2014, s. 420-441; Vanhaverbeke \& Chesbrough, 2014), wdrażania strategii (Casadesus-Masanell \& Zhu, 2013, s. 464-482; Teece, 2010), zrównoważonego rozwoju uwzględniającego wartości społeczne i środowiskowe (Bocken i in., 2014; Schaltegger i in., 2012) czy przedsiębiorczości społecznej (Tykkyläinen \& Ritala, 2021). Również w koncepcjach modelu biznesowego wskazuje się na konieczność zainteresowania tworzeniem wartości społecznej, oprócz tworzenia wartości ekonomicznej (Dohrmann, Raith \& Siebold, 2015, s. 127-154; Hausner \& Zmyślony, 2015; Lowitt, 2013; Porter \& Kramer, 2017). Porter i Kramer (2017) nazywają to wartością wspólną.

Uważa się, że tworzenie unikalnej wartości i przewagi konkurencyjnej należy rozwijać przez innowacje, które powinny być wpisane w „kod genetyczny” modelu biznesowego. Chesbrough (2010) dopowiada, że model powinien być otwarty na 
otwarte innowacje i powinien sprzyjać ich komercjalizowaniu. Słowem, powinien to być otwarty model biznesowy.

Coraz większego znaczenia nabiera zapraszanie do współpracy niezdefiniowanych społeczności użytkowników/klientów. Przepływ wiedzy między firmą a jej otoczeniem zewnętrznym jest dwukierunkowy. Współpraca tego rodzaju wymaga zbudowania otwartych platform w internecie (crowdsourcing, koprodukcja czy koopetycja, open sourcing).

Obecnie uważa się, że umiejętność definiowania i redefiniowania modelu biznesowego organizacji należy do kluczowych kompetencji służących budowaniu wartości przedsiębiorstwa (Rudny, 2013, s. 98-108).

Autor niniejszego opracowania sugeruje kierunki dalszych badań, które powinny służyć wyjaśnieniu:

- procesów zmian w kierunku rozwoju kultury innowacyjnej firmy, zwiększenia „przepuszczalności granic firmy” na innowacje z zewnątrz oraz barier z tym związanych. Należy odpowiedzieć na pytanie, czy proces ten dokonuje się w ramach modelu biznesowego czy też wymaga jego zmiany,

- doświadczeń czy też praktyk firm, których modele biznesowe są integrowane z modelami sąsiednich ogniw łańcucha wartości w oparciu o platformę współpracy. W tym przypadku pytanie dotyczy tego, jakie są mechanizmy, które wymuszają reakcję i zmianę modelu biznesowego,

- tego, jak przedsiębiorstwa zarządzają własnością intelektualną w celu budowania wartości swojej organizacji. Czy własność intelektualna jest wyłącznie przedmiotem ochrony czy też strategicznym elementem aktywów przedsiębiorstwa? Czy firmy traktują badania i rozwój oddzielnie od modelu biznesowego firmy?

\section{Bibliografia}

Afuah, A. (2004). Business Models: A Strategic Management Approach. Boston: McGraw-Hill/Irwin.

Amit, R., \& Zott, C. (2001). Value creation in e-business. Strategic Management Journal, 22, 493-520. https://doi.org/10.1002/smj.187

Amit, C., \& Zott, R. (2008). The fit between product market strategy and business model: Implications for firm performance. Strategic Management Journal, 29(1), 1-26. http://dx.doi.org/10.1002/smj.642

Bever, D. van, Bartman, T., \& Christensen, C.M. (2020). Cała prawda o innowacjach $w$ sferze modeli biznesowych. Warszawa: ICAN Institute.

Bocken, N.M.P., Short, S.W., Rana, P., \& Evens, S. (2014). A literature and practice review to develop sustainable business model archetypes. Journal of Cleaner Production, 65.

https://doi.org/10.1016/j.jclepro.2013.11.039

Casadesus-Masanell, R., \& Ricart, J.E. (2010). From Strategy to Business Model and Onto Tactics. Long Range Planning, 43(2), 195-215.

Casadesus-Masanell, R., \& Zhu, F. (2013). Business model innovation and competitive imitation: The case of sponsor - based business models. Strategic Management Journal, 34(4), 464-482.

https://doi.org/10.1002/smj.2022 
Chanal, V., \& Caron-Fasan, M.L. (2010). The difficulties involved in developing business models open to innovation communities: The case of a crowdsourcing platform.M@n@gement, 13(4),318-340. https://doi.org/10.3917/mana.134.0318

Chesbrough, H. (2003). Open Innovation: The New Imperative for Creating and Profiting from Technology. Boston: Harvard Business School Publishing Corporation.

Chesbrough, H. (2006). Open Business Models: How to Thrive in the New Innovation Landscape. Boston: Harvard Business School Press.

Chesbrough, H. (2007). Business Model Innovation: It's Not Just about Technology Anymore. Strategy and Leadership, 35(6). http://dx.doi.org/10.1108/10878570710833714

Chesbrough, H. (2010). Business Model Innovation: Opportunities and Barriers. Long Range Planning, 43. https://doi:10.1016/j.Irp.2009.07.010

Chesbrough, H., \& Rosenbloom, R.S. (2002). The Role of the Business Model in Capturing Value from Innovation: Evidence from Xerox Corporation's Technology Spin-off Companies. Industrial and Corporate Change, 1(3), 529-555.

Curley, M., \& Salmelin, B. (2013). Open Innovation 2.0: A New Paradigm. Pobrane z: https://uc-dk.dk/ uasnet/wp-content/uploads/Open-Innovation-2.0-Salmelin.pdf

Dohrmann, S., Raith, M., \& Siebold, N. (2015). Monetizing social value creation: A business model approach. Entrepreneurship Research Journal, 5, 127-154.

https://doi.org/10.1515/erj-2013-0074

Dolińska, M. (2017). Otwarte innowacje w internecie. Przedsiębiorczość i Zarządzanie, 18(4/1), 73-83.

Dyer, J.H., Gregersen, H., \& Christensen, C.M. (2012). DNA innowatora. Zostań mistrzem we wdrażaniu innowacji! Warszawa: Harvard Business Review Polska.

Dzisah, J., Etzkowitz, J.H. (2008). Triple helix circulation: The heart of innovation and development. International Journal of Technology Management \& Sustainable Development, 7(2), 101-115. https://doi.org/10.1386/IJTM.7.2.101_1

Edersheim, E.H. (2010). Przesłanie Druckera. Zarządzanie oparte na wiedzy. MT Biznes, 61-63.

Evans, S., Bergendahl, M.N., Gregory, M., Ryan, C., \& Tan, A. (2009). Towards a Sustainable Industrial System: With Recommendations for Education, Research, Industry and Policy. Cambridge: University of Cambridge, Institute for Manufacturing.

Foss, N.J., \& Saebi, T. (2018). Business models and business model innovation: Between wicked and paradigmatic problems. Long Range Planning, 51(1). https://doi.org/10.1016/j.Irp.2017.07.006

Geissdoerfer, M., Vladimirova, D., \& Evans, S. (2018). Sustainable business model innovation: A review. Journal of Cleaner Production, 198, 401-416. https://doi.org/10.1016/j.jclepro.2018.06.240

Gulati, R., Nohria, N., \& Zahher, A. (2000). Strategic networks. Strategic Management Journal, 21(3), 203-215.

Hausner, J., \& Zmyślony, M. (2015). Firma-IDEA - Nowe podejście do wartości w biznesie. Sopot: Europejskie Forum Nowych Idei.

Hearn, G., \& Pace, C. (2006). Value-creating ecologies: understanding next generation business systems. Foresight, 8(1), 55-5. https://doi.org/10.1108/14636680610647147

Itami, H., \& Nishino, K. (2010). Killing two birds with one stone: Profit for now and Learning for the future. Long Range Planing, 43(2-3), 364-369. https://doi.org/10.1016/j.Irp2009.07.007

Jabłoński, M. (2016). Podejście scenariuszowe w procesie projektowania i modyfikacji modeli biznesu sektorów kreatywnych. Przedsiębiorstwo we Wspótczesnej Gospodarce - Teoria i Praktyka, 19(4), 49-64. https://doi.org/10.19253/reme.2016.04.004

Johnson, M.W., Christensen, C.M., \& Kagermann, H. (2008). Reinventing your business model. Harvard Business Review, 86(12), 57-68.

Jørgensen, F., \& Ulhøi, J. (2010). Entrepreneurial emergence in the field of M-Commerce: A generic business model reconceptualization. Journal of e-Business, 9(1/2), 25-32.

Komitet Regionów. (2013). Opinia „Zlikwidować przepaść innowacyjną” (2013/C 218/03) (Dz.Urz. UE C 218/12, 30.07.2013). 
Koźmiński, A.K. (2004). Zarządzanie w warunkach niepewności. Podręcznik dla zaawansowanych. Warszawa: Polskie Wydawnictwo Naukowe.

Lakhani, K.R., \& Hippel, E. von (2004). How open source software works: "free" user-to-user assistance. W: Produktentwicklung mit virtuellen Communities (s. 303-339). Berlin: Gabler Verlag.

Linder, J., \& Cantrell, S. (2000). Changing Business Models: Surveying the Landscape. Accenture Institute for Strategic Change.

Lowitt, E. (2013). The Collaboration Economy: How to Meet Business, Social, and Environmental Needs and Gain Competitive Advantage. New York: John Wiley \& Sons.

Magretta, J. (2013). Tajniki modelu biznesowego. Warszawa: Harvard Business Review Polska.

Massa, L. \& Tucci, C.L. (2014). Business model innovation. The Oxford Handbook of Innovation Management, 20(18), 420-441.

Massa, L., Tucci, C.L., \& Afuah, A. (2017). A Critical Assessment of Business Model Research. Academy of Management Annals, 11(1), 73-104. https://doi.org/10.5465/annals.2014.0072

Morris, M., Schindehutte, M., \& Allen, J. (2005). The entrepreneur's business model: Toward a unified perspective. Journal of Business Research, 58(6), 726-735. https://doi.org/10.1016/j.jbusres.2003.11.00

Nambisan, S., \& Sawhney, M. (2009). Making the most of the global brain for innovation. International Commerce Review, 8(2), 128-135.

Onetti, A., Zuchcella, A., Jones, M.V., \& McDougall-Covin, P.P. (2012). Internationalization, innovation and entrepreneurship: business models for new technology-based firms. Journal of Management \& Governance, 16(3), 337-368. https://doi.org/10.1007/s10997-010-9154-1

Osterwalder, A., Pigneur, Y., \& Tucci, C.L. (2005). Clarifying business models: Origins present and future of the concept. Communications of the Association for Information Systems, 16, 1-25.

https://doi.org/10.17705/1CAIS.01601

Osterwalder, A., \& Pigneur, Y. (2010). Business Model Generation: A Handbook for Visionaries, Game Changers, and Challengers (1). London: John Wiley \& Sons.

Peteraf, M.A. (1993). The cornerstones of competitive advantage: A resource-based view. Strategic Management Journal, 14, 179-191. https://doi.org/10.1002/smj.4250140303

Pokojski, Z. (2017). W poszukiwaniu modelu organizacji zarządzającej innowacjami w formule open innovation - studium przypadku. Prace Naukowe Młodych Ekonomistów Wyższej Szkoły Bankowej w Gdańsku, 49.

Pokojski, Z. (2018). A model of cooperation platform for entities involved in the agricultural market open to innovations in Poland. Economic and Environmental Studies, 18(2/46), 809-823. https://doi.org/10.25167/ees.2018.46.21

Porter, M. (1996). Competitive advantage, agglomeration economies, and regional policy. International Regional Science Review, 19(1-2), 85-90. https://doi.org/10.1177\%2F016001769601900208

Porter, M. (2001). Strategy and the Internet. Harvard Business Review, 79, 62-79.

Porter, M. (2006). How competitive forces shape strategy. Readings in Strategic Management, $133-143$. https://doi.org/10.1007/978-1-349-20317-8_10

Porter, M.E., \& Kramer, M.R. (2017). Tworzenie wartości dla biznesu i społeczeństwa. Harvard Business Review Polska, 99, 38-57.

Rudny, W. (2013). Model biznesowy a tworzenie wartości. Studia Ekonomiczne, 141, 98-108.

Saebi, T., \& Foss, N.J. (2015). Business Models for Open Innovation: Matching Heterogenous Open Innovation Strategies with Business Model Dimensions. European Management Journal, 33(3), 201-213. https://doi.org/10.1016/j.emj.2014.11.002

Schaltegger, S., Lüdeke-Freund, F., \& Hansen, E.G. (2012). Business cases for sustainability: The role of business model innovation for corporate sustainability. International Journal of Innovation and Sustainable Development, 6(2), 95-119. https://doi.org/10.1504/IJISD.2012.046944

Shafer, S.M., Smith, H.J., \& Linder, J.C. (2005). The power of business model. Business Horizons, 48(3), 199-207. https://doi.org/10.1016/j.bushor.2004.10.014 
Sopińska, A. (2013). Otwarte innowacje bazujące na mądrości „tłumu” - podstawa sukcesu współczesnego przedsiębiorstwa. Zarządzanie i Finanse, 11(4), 287-302.

Teece, D.J. (2010). Business Models, Business Strategy and Innovation. Long Range Planning, 43(2-3), 172-194. https://doi.org/10.1016/j.Irp.2009.07.003

Tykkyläinen, S., \& Ritala, P. (2021). Business model innovation in social enterprises: An activity system perspective. Journal of Business Research, 125, 684-697. https://doi.org/10.1016/j.jbusres.2020.01.045

Upward, A., \& Jones, P. (2016). An ontology for strongly sustainable business models: Defining an enterprise framework compatible with natural and social science. Organization \& Environment, 29(1), 97-123. https://doi.org/10.1177/1086026615592933

Vanhaverbeke, W., \& Chesbrough, H. (2014). A classification of open innovation and open business models. W: H. Chesbrough, W. Vanhaverbeke, J. West (eds.), New Frontiers in Open Innovation. London: Oxford University Press.

Wells, P. (2016). Economies of scale versus small is beautiful: A business model approach based on architecture, principles and components in the beer industry. Organization \& Environment, 29(1), 36-52. https://doi.org/10.1177\%2F1086026615590882

Zott, C., \& Amit, R. (2010). Business model design: An activity system perspective. Long Range Planning, 43(2-3), 216-226. https://doi.org/10.1016/j.Irp.2009.07.004

Zott, C., \& Amit, R. (2015). Business model innovation: Toward a process perspective. W: The Oxford Handbook of Creativity, Innovation, and Entrepreneurship (395-406). Oxford: Oxford University Press.

Zott, C., Amit, R., \& Massa, L. (2010). The Business Model: Theoretical Roots, Recent Developments and Future Research. Navara: IESE Business School.

Zott, C., Amit, R., \& Massa, L. (2011). The business model: Recent developments and future research. Journal of Management, 37(4), 1019-1049. https://doi.org/10.1177\%2F0149206311406265 